UDC 343.2/.7

DOI https://doi.org/10.32849/2663-5313/2021.9.19

Stanislav Mozol,

Doctor of Law, Senior Researcher, Associate Professor at the Department of Criminology and Criminal Execution Law, National Academy of Internal Affairs, 1, Solomianska square, Kyiv, Ukraine, postal code 03035, Stanislav_Mozol@ukr.net

ORCID: orcid.org/0000-0002-2226-7908

Hennadii Polishchuk,

PhD in Law, Associate Professor, Professor at the Department of Criminology and Criminal Execution Law, National Academy of Internal Affairs, 1, Solomianska square, Kyiv, Ukraine, postal code 03035, Hennadii_Polishchuk@ukr.net

ORCID: orcid.org/0000-0002-0829-2621

\title{
Anastasiia Ternavska,
}

PhD in Law, Chief Specialist at the Department for Activities of the Disciplinary Chambers of the Office for Liability of Judges and Prosecutors of the Secretariat, High Council of Justice, 1, Solomianska square, Kyiv, Ukraine, postal code 03035, Anastasiia_Ternavska@ukr.net

ORCID: orcid.org/0000-0003-2624-7645

Mozol, Stanislav, Polishchuk, Hennadii, Ternavska, Anastasiia (2021). Perspectives for the imposition of individual types of punishment in Ukraine. Entrepreneurship, Economy and Law, 9, 130-135, doi: https://doi.org/10.32849/2663-5313/2021.9.19

\section{PERSPECTIVES FOR THE IMPOSITION OF INDIVIDUAL TYPES OF PUNISHMENT IN UKRAINE}

Abstract. Purpose. The aim of the article is to characterize the main trends in the imposition of punishment in Ukraine, its particular types, as well as a scientific analysis of the recent draft laws in this field. Results. The relevance of the article is that one of the components of public policy on combating crime is punishment, which is the most important means of influencing potential offenders and persons who have already committed criminal offenses to deter them from committing crimes (general prevention) or same commission of repeated crimes (special prevention). Thus, the effectiveness of the policy on criminal penalties largely determines the effectiveness of the entire system of combating crime in Ukraine and is one of the significant and complex problems of domestic legal science and criminal policy of the state. The article studies the implementation of criminal punishment and its individual types on the basis of official statistical data, which has an independent significance for both legislative and law enforcement activities. It is proved that the criminal policy of Ukraine is characterized by a steady trend of increasing use of alternatives to imprisonment and release from punishment. The calculated statistical indicators show a situation when exemption from criminal punishment with probation is applied in more cases than other types of criminal punishment. It is emphasized that the fight against crime is a complex, systematic and multifaceted activity in the field of social management and has its own goals, objectives, directions, object, subjects, means, principles, the correct definition of which is the key to the effectiveness of this activity. It is found that around the world, criminal policy increasingly advocates alternatives to isolating those responsible for criminal offenses from society. Conclusions. It is concluded that the criminal policy of Ukraine is characterized by a steady trend of increasing use of alternatives to imprisonment and release from punishment. As illustrated by the above calculations, exemption from criminal punishment with probation is applied in more cases than other types of criminal punishment. At the same time, the share of such persons is gradually decreasing.

Key words: punishment, penalization, criminal record, criminal offense, crime, convicts, probation supervision. 


\section{Introduction}

In view of new objective realities connected with the implementation of the officially proclaimed course for integration into Europe in all sectors of public life, the development of the legal State in Ukraine and the reform of national legislation on combating crime, the content of this activity changes accordingly. The problem of effectiveness of such activity does not lose its relevance, because in the current political and socio-economic situation the counteraction to crime becomes one of the important and actual vectors of social stabilization.

One of the components of public policy on combating crimeis punishment, which is the most significant measures against potential offenders and persons who have already committed criminal offenses, with the aim of preventing them from committing crimes (general prevention) or from committing repeated crimes (special prevention). Therefore, the effectiveness of policy on criminal punishment largely determines the effectiveness of the entire system of countering crime in Ukraine and is one of the significant and complex problems of domestic legal science and criminal policy of the State.

In specific domestic and foreign literature, the issues of effective imposition of criminal punishment and its individual types are covered in the works by T.A. Bushuieva, I.M. Halperin, P.S. Dahel, A.P. Kozlov, A.I. Korobieiev, V.N. Kudriavtsev, N.F. Kuznietsova, N.A. Lopashenko, A.A. Muzyka, V.V. Stashys, Ye.L. Streltsov, P.L. Fris, O.I Shynalskyi, and others. However, despite the unconditional importance of scientific study in this field, some of the challenging issues of the subject are poorly studied. Moreover, literature review fragmentary reveals the problems of modern judicial practice in Ukraine, in particular, the application of certain types of punishment.

The aim of the article is to characterize the main trends in the imposition of punishment in Ukraine, its specific types, as well as a scientific analysis of the recent draft laws in this field.

2. General principles of criminal punishment

As it is known, the fight against crime is a complex, systemic and multifaceted activity in the field of social administration that has its objectives, tasks, vectors, object, actors, means, principles, proper, the proper definition of which guarantees effectiveness of this activity.

Considering the objective of criminal policy of the State, it should be noted that it is impossible to eradicate criminal offenses as a kind of social practice, to eliminate their determinants completely, as well as it is unrealistic and scientifically unjustified to overcome crime. The only realistic tasks required in the fight against crime are to retain the number and spread of criminal offenses at a minimum level acceptable to society; to reduce the danger of such encroachments; to prevent criminal activity as a business, occupation; to restrict the interrelation of criminality and other negative social phenomena (especially corruption and shadow economy); to eliminate or reduce socially negative consequences of crime.

The public danger of criminal offenses and the offender is reflected in the sanctions of criminal law through such measures as the types and extent of punishment, that is, in the quantitative terms of the criminalization of such offenses, their penalization, which is the process of determination of punishability of socially dangerous acts, as well as their practical punishability, namely, the process of imposition of a criminal punishment in the judicial practice (Korobeev, 1987, p. 137). The similar definition is formulated by P.S. Dagel and T.A. Bushuieva, who argue that the penalty is statutory consolidation and practical implantation of the types and amount of punishment imposed for crimes (Dagel, Bushueva, 1981, p. 49).

Therefore, penalisation can be both legislative (determination of type and limits of punishment by a criminal provision) and law-enforcement (imposition of punishment in practice) (Turlova, 2015, p. 121).

Attempts to assess the conformity of criminal punishment with actual application of its certain types (legal penalisation) as the conceptual task of combating crime should be based on empirical method, in particular statistical analysis of law application practice (Polishchuk, 2021, p. 207).

Statistics of the State Judicial Administration of Ukraine (Judicial power of Ukraine, 2021) (form of statistical report no. 6 "Report on persons brought to criminal responsibility and types of criminal punishment" (till 2018, "Report on the number of persons convicted, justified, in whose respect cases are closed, a mentally incompetent person, in whose respect compulsory measures of medical character and types of criminal punishment are applied)) enable to analyse the state of affairs and trends in criminal punishment in Ukraine, in particular to study the structure of criminal records and the practice of imposing certain types of punishment.

One of the steady trends in criminal policy is the strengthening of humanitarian tendencies in the application of criminal punishment, which is evident in the stable decrease of absolute and relative parameters of punishment in the form of imprisonment. For example, while in the Soviet times in 60-70-s, the share of imprisonment in the structure of criminal records was $53-66 \%$ of convicted persons (Cherkasov, 
2004, p. 143), up to 2000 years it decreased twice to $32 \%$.

According to the diagram in Fig. 1, in 2010, the indicator (number of persons sentenced to imprisonment for a certain term and lifelong imprisonment) decreased to $24,2 \%$, and in 2020, (Fig. 2) it was 19,1\%.

It should be considered as a positive trend in criminal policy in Ukraine. The overwhelming majority of scientists, who have studied this problem, argue that the application of severe punishment (in particular imprisonment) has practically no preventive effect. For example, studies of German criminologists (Ortmann, 1993) enable Kh. Kuri and O. Ilchenko to argue that "the results of criminological studies unanimously reveal that severe criminal punishment has, if any, a slight impact on crime level, and has a small preventive effect. Moreover, punishment in the form of imprisonment has significant negative consequences. Their application requires additional intensive rehabilitation measures to motivate people to change behaviour. A simple "serving one's term in prison" as punishment causes, as a rule, only fixing of criminal behaviour, habits and attitudes, due to the powerful influence of the prison subculture" (Kury, Ilchenko, 2013).

3. Development of alternative types of punishment

Therefore, criminal policy increasingly advocates alternatives to isolating those guilty of criminal offenses from society. The Draft Law of Ukraine "On amendments to the Criminal Code of Ukraine, the Criminal Procedure Code of Ukraine with regard to the development of the system of probation, increase of alternatives to deprivation of liberty and an enabling environment for reducing recidivism" (Draft Law of Ukraine On amendments to the Criminal Code of Ukraine, the Criminal Procedure Code of Ukraine with regard to the development of the system of probation, increase of alternatives to deprivation of liberty and an enabling environment for reducing recidivism, 2021) reveals the legislative attempts to join this global trend, because one of its proposals is the introduction of a new kind of punishment, that is, probation supervision, which provides for the limited rights and freedoms of the defendant, with a view to correct and prevent committing new offenses, without the isolation of the convicted from the society.

In our opinion, we should pay attention to controversial provisions of the Law, such as: in connection with the proposed amendments to the Criminal and Criminal Procedure Codes of Ukraine, it is expedient to make corresponding changes to the Law of Ukraine "On Probation"; Article $59^{1}$ of the Draft Law "On Probation Supervision" does not specify which categories of convicted persons should be subject to probation supervision (the grav-

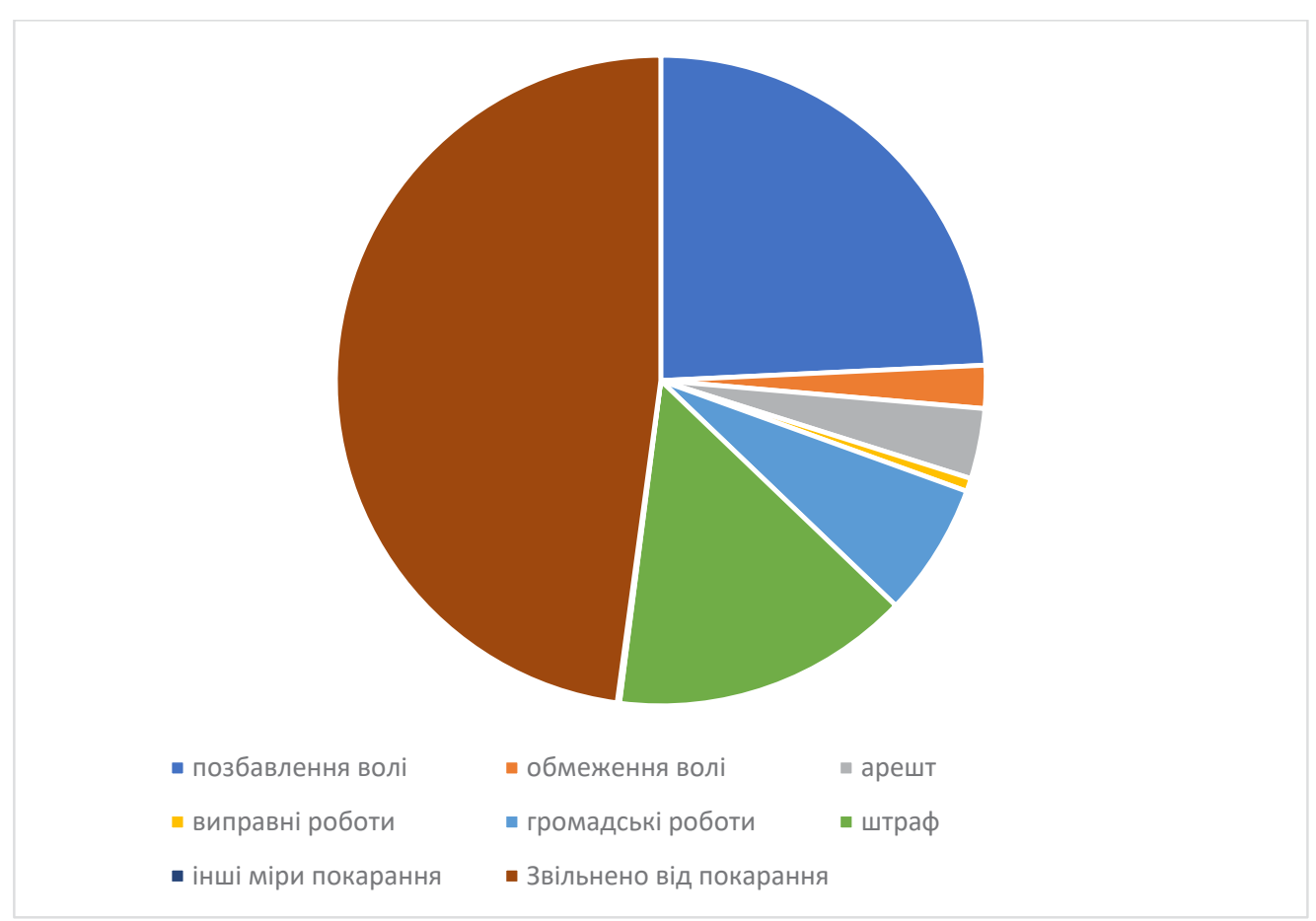

Figure 1. Structure of criminal records in Ukraine as of 2010 


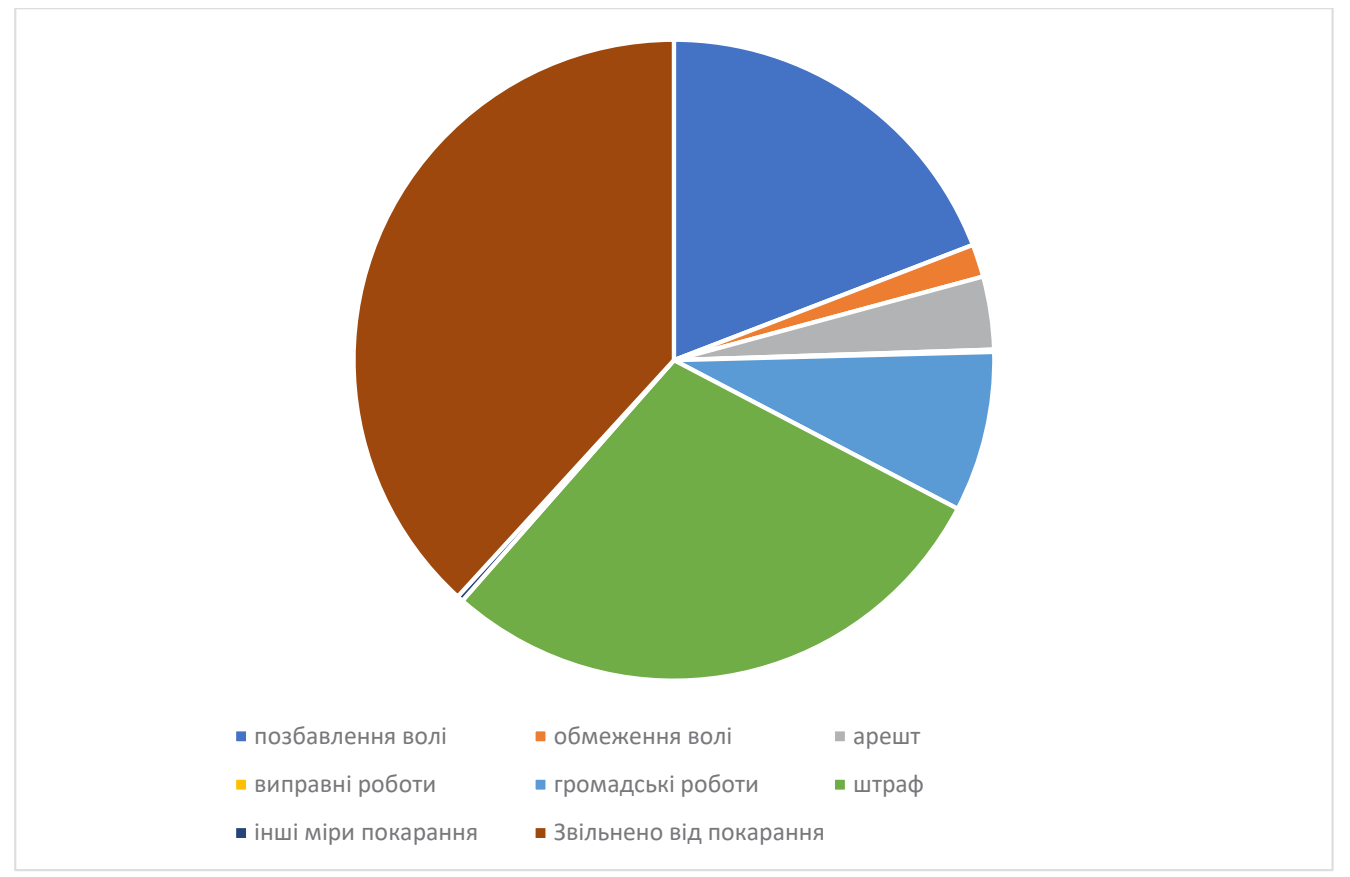

Figure 2. Structure of criminal records in Ukraine as of 2020

ity of the crime, recidivism, convictions, form of guilt, etc.), that is, it is necessary to consider both the degree of danger of the offense and the social danger of the offender (in the case of grave and exceptionally grave crimes, such punishment is out of the question, as in this case it cannot ensure the balance between public security and fair punishment for the crime committed); it is not quite clear whether the law-makers are logical to remove from the list of criminal punishments the restriction of liberty, which has been applied for a long time to a sufficiently large category of convicted persons (in 2020, these are 1116 convicted persons (1,7\% of the totality) and which, with proper organization of its execution is a rather effective type of punishment, with which the proposed probation supervision could co-exist, because they absolutely do not interfere with each other (so why the law-makers have provided for such types of punishment, which in practice are not applied in general or cases of such punishment are rare: corrective work, detention in a disciplinary battalion, service restriction for servicemen, deprivation of the right to take certain positions or to engage in certain activities (as the main punishment)); the proposal to limit the use of punishment in the form of arrest by a category of military personnel is also insufficiently grounded.

\section{Conclusions}

The authors' study of modern judicial practice in Ukraine shows that Ukrainian criminal policy is characterized by a steady trend towards increasing application of alternative to deprivation of liberty types of punishment and exemption from punishment. The above calculations proves that exemption from criminal punishment with probation is applied in more cases than other types of criminal punishment. At the same time, the share of such persons is gradually decreasing. For example, the share of the persons who have been released on probation in the totality of the convicted persons was $47.9 \%$ in 2010 , and $38.2 \%$ in 2020 .

Therefore, the comparative analysis of actual penalisation in Ukraine for 2010-2020 years in the context of quantitative evaluation and prospects of imposition of certain types of punishment permits assuming that the process of improving the system of punishment and its further humanization will not be limited.

\section{References:}

Korobeev, A.I. (1987) Sovetskaya ugolovno-pravovaya politika: problemy kriminalizatsii i penalizatsii [Soviet criminal law policy: Problems of criminalization and penalization]. Vladivostok, Dalnevostochnyi University, 268 p. (in Russian). 
Dagel, P.S., Bushueva, T.A. (1981) Penalizatsiya prestupnykh posyagatelstv na okruzhayushchuyu prirodnuyu sredu [Penalization of criminal encroachments on the environment]. Jurisprudence, 6, 49-55. (in Russian).

Turlova, Y.A. (2015) Problemy penalizatsii zlochyniv proty dovkillia v Ukraini [Problems of penalization of anti-doping cases in Ukraine]. Jurnalul juridic national: teorie şi practică, 2/1 (12), 120-125. (in Ukrainian).

Polishchuk, H.S. (2021). Shchodo kilkisnoi otsinky ta perspektyv zastosuvannya okremykh vydiv pokarannya $\mathrm{v}$ Ukrayini [Regarding the quantitative assessment and prospects of application of certain types of punishment in Ukraine]. Ways of development of legal science in today's conditions: Proceedings of the XI Intermational scientific-practical conference (pp. 207-210). K.: DUIT. (in Ukrainian)

Sudova vlada Ukrainy [Judicial power of Ukraine]. (2021). court.gov.ua. Retrieved from https://court.gov.ua/inshe/sudova_statystyka/ (in Ukrainian).

Cherkasov, S.V. (2004) Rozvytok systemy pokaran, alternatyvnykh pozbavlennyu voli (istorychnyy narys) [Development of a system of punishments alternative to imprisonment (historical essay)]. Bulletin of the Odessa Institute of Internal Affairs, 3 (Part II), 141-145. (in Ukrainian)

Ortmann, R. (1993). Prisonisierung. In: Kaiser, G., Kerner, H.-J., Sack, F., Schellhoss, H. (Hrsg.), Kleines Kriminologisches Wörterbuch. Heidelberg: C.F. Müller, 402-409. (in German).

Kury, Kh., Ilchenko, O. (2013) Effektivnost nakazaniya: rezultaty mezhdunarodnykh issledovaniy [The effectiveness of punishment: Results of international studies]. Actual Problems of Economics and Law, 2(26), 240-256. (in Russian).

Proekt Zakonu pro vnesennya zmin do Kryminalnoho kodeksu Ukrainy, Kryminalnoho protsesualnoho kodeksu Ukrayiny shchodo rozvytku systemy probatsii, zbilshennya alternatyv pozbavlennyu voli ta stvorennya umov dlya znyzhennya retsydyvnoyi [Draft Law of Ukraine On amendments to the Criminal Code of Ukraine, the Criminal Procedure Code of Ukraine with regard to the development of the system of probation, increase of alternatives to deprivation of liberty and an enabling environment for reducing recidivism]. (2021). rada.gov.ua. Retrieved from http://w1.c1.rada.gov.ua/pls/zweb2/webproc4_1?pf3511=71629 (in Ukrainian).

\section{Станіслав Мозоль,}

доктор юридичних наук, стариий науковий співробітник, доцент кафедри кримінології та кримінально-виконавчого права, Національна академія внутрішніх справ, площа Солом'янська, 1, Киї, Україна, індекс 03035, Stanislav_Mozol@ukr.net

ORCID: orcid.org/0000-0002-2226-790 $\overline{8}$

\section{Геннадій Полішук,}

кандидат юридичних наук, доцент, професор кафедри кримінологї та кримінально-виконавчого права, Національна академія внутрішніх справ, площа Солом'янська, 1, Київ, Украйна, індекс 03035, Hennadii_Polishchuk@ukr.net

ORCID: orcid.org/0000-0002-0829-2621

\section{Анастасія Тернавсъка,}

кандидат юридичних наук, головний спеціаліст відділу забезпечення діяльності Дисциплінарних палат Управління з питань відповідальності суддів і прокурорів секретаріату, Вища рада правосуддя, площа Солом'янська, 1, Київ, Україна, індекс 03035, Anastasiia_Ternavska@ukr.net ORCID: orcid.org/0000-0003-2624-7645

\section{ДЕЯКІ ПИТАННЯ ЩОДО ПЕРСПЕКТИВ ЗАСТОСУВАННЯ ОКРЕМИХ ВИДІВ ПОКАРАННЯ В УКРАЇНІ}

Анотація. Метою статті є надання характеристики основних тенденцій застосування покарання в Україні, окремих його видів, а також науковий аналіз останніх законопроєктів у цій сфері Результати. Актуальність статті полягає в тому, що одним зі складників державної політики у сфеpi протидії злочинності є інститут покарання, що є найбільш вагомим засобом впливу на потенційних правопорушників та осіб, які вже вчинили кримінальні правопорушення, з метою утримання їх від вчинення злочинів (загальна превенція) або ж учинення повторних злочинів (спеціальна превенція). Отже, дієвість політики у сфері кримінальних покарань значною мірою зумовлює ефективність усієї системи протидії злочинності в Україні та є однією зі значущих і складних проблем вітчизняної правової науки та кримінальної політики держави. У статті на основі офіційних статис- 
тичних відомостей досліджено реалізацію кримінального покарання та його окремих видів, що має самостійне значення як для законотворчої, так і для правозастосовної діяльності. Доведено, що кримінальна політика України характеризується стійкою тенденцією до дедалі ширшого застосування альтернативних позбавленню волі видів покарань і звільнення від покарання. Розраховані статистичні показники засвідчують ситуацію, коли звільнення від кримінального покарання 3 випробуванням застосовується в більшій кількості випадків, ніж інші види кримінального покарання. Наголошено на тому, що протидія злочинності є складною, системною та багатоаспектною діяльністю у сфері соціального управління, вона має свої цілі, завдання, напрями, об'єкт і суб'єктів, засоби та принципи, правильне визначення яких є запорукою ефективності цієї діяльності. 3'ясовано, що в усьому світі кримінальна політика дедалі більше схиляється на користь альтернатив ізоляції від суспільства осіб, винних у вчиненні кримінальних правопорушень. Висновки. Констатовано, що кримінальна політика України характеризується стійкою тенденцією до дедалі ширшого застосування альтернативних позбавленню волі видів покарань та звільнення від покарання. Як ілюструють наведені розрахунки, звільнення від кримінального покарання з випробуванням застосовується в більшій кількості випадків, ніж інші види кримінального покарання. Водночас характерне також поступове зменшення частки таких осіб.

Ключові слова: покарання, пеналізація, судимість, кримінальне правопорушення, злочин, засуджені, пробаційний нагляд.

The article was submitted 15.09.2021

The article was revised 06.10.2021

The article was accepted 27.10.2021 